Vol.15, No. 57, October, 2020, 963-970

\title{
FINITE ELEMENT ANALYSIS OF EMBANKMENTS ON SOFT CLAY
}

\author{
Moamen E. Abd El Raouf \\ Civil Engineering Department, Faculty of Engineering, Al- Azhar University, Qena, Egypt. \\ E-mail: moamenabdelmontaleb@azhar.edu.eg
}

\begin{abstract}
:
Soft clay soil is characterized by high compressibility and low shear strength, so the settlement is the major problem facing the embankment constructed on soft clay soils and causes an increase in the cost of maintenance. Numerical analysis has been carried out to study some parameters affect the settlement of embankment founded on soft clay such as, the clay thickness $\left(\mathrm{h}_{\mathrm{c}}\right)$ and the width of the embankment base $(\mathrm{B})$, and the stiffness of clay layer. The lateral extrusion due to the settlement of the embankment was also included. The results of the finite element analysis were verified using field and the traditional method results. Numerical analysis was performed using the GEO5 finite element program. Finally, the results of the finite element analysis were discussed in detail.
\end{abstract}

KEYWORDS: Embankments, Soft clay, Numerical analysis, Modulus of Elasticity, Settlement.

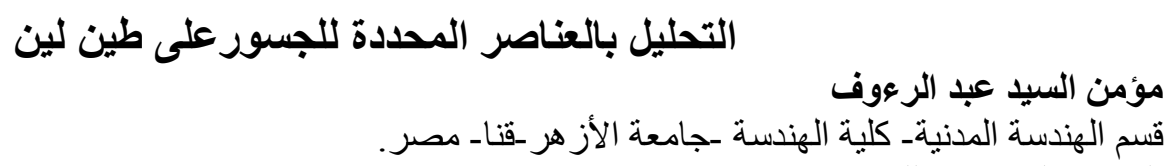

البريد الإليكتروني للباحث: E-mail: moamenabdelmontaleb@azhar.edu.eg

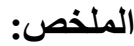

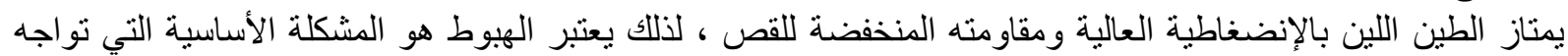

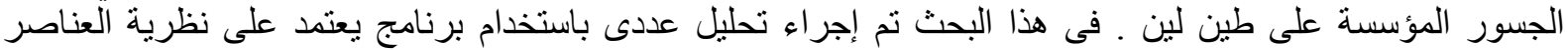

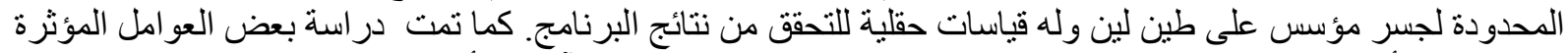

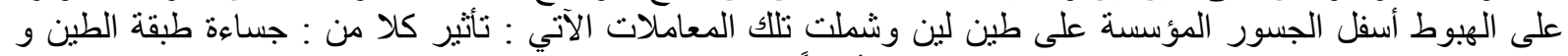

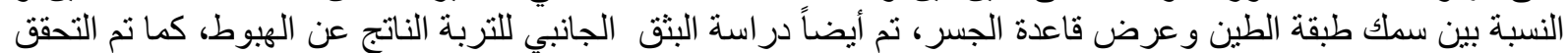

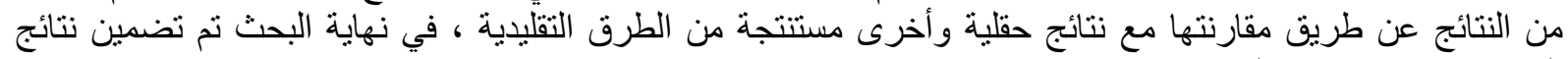

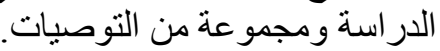

\section{INTRODUCTION}

الكلمات المفتاحية : الجسور، الطين اللين ، التحليل العددى ، معامل المرونة ، الهبوط.

The shear strength of the soft clay soil is low, so the increase in the stress due to the construction of the embankment on soft clay soils must be relatively small. Also, the soft clay soil is characterized by high compressibility $[1,2,3]$. The settlement is the main consideration in the design of the embankment constructed on soft clay and consider as the major problem facing the highway embankment and causes an increase in the cost of maintenance. The settlement develops with the time under embankments as a result of the excess pore pressure dissipation, then the applied load transfers gradually to the soil particles.

The main challenge is the prediction of the accurate total settlement, so there is a need to study the factors that affect the settlement to enhancement predict the long-term stability of highway embankments founded on soft clay [4]. The most practical solution for the prediction 
of consolidation rates is based on Terzaghi's theory of consolidation [5]. Many researchers studied the settlement under embankment on soft clay $[6,7,8,9,10]$.

Consolidation settlement under embankment constructed over soft clay soils is a two- or three-dimensional consolidation [11]. Several theories were developed to study and analyses the two-dimensional consolidation [12]. These theories have some assumption such as:

(1) Clay is isotropic

(2) The coefficient of consolidation is constant

(3) Consolidation parameters were determined in the horizontal direction.

Finite element programs were developed to analyze two- and three-dimensional consolidation.

Complete knowledge of the stress-strain at all construction stages are required to complete the numerical analysis using finite element programs $[13,14]$. Recently, two- dimensional and three- dimensional consolidation models have been developed to describe the real behaviour of soft clay under the effect of loads and ensure more accuracy of consolidation settlement calculation.

For the sake of maintenance, it is preferable to calculate the long-term settlement with the sufficient dissipation of excess pore water pressure and the lateral displacement after the completion of the construction [15].

In the present paper, numerical analysis has been carried out to study some parameters that affect the settlement under embankment founded on soft clay using case histories. The relation between the clay thickness $\left(\mathrm{h}_{\mathrm{c}}\right)$ and the width of the embankment base $(\mathrm{B})$, and the stiffness of the clay layer were studied. The lateral displacement due to the settlement of the embankment was also included. The total settlement, the lateral extrusion and the dissipation of excess pore pressure were determined using a GEO5 finite element program to study the parameters that affect the settlement under an embankment founded on soft clay soil.

\section{SETTLEMENT CALCULATION}

\subsection{Classical Methods}

The total settlement equals the sum of an immediate settlement, primary consolidation, and secondary consolidation. The consolidation settlement due to embankment construction can be calculated by the traditional method depends on Terzaghi's theory of consolidation. The conventional analytical analysis can be performed using manual calculation or computer programs. The primary consolidation settlement of the natural sedimentary clays can be determined by the following equations [16]:

For normally consolidated clay

$$
s_{p}=\frac{C_{c} H}{1+e_{0}} \log \left(\frac{\sigma_{0}^{\prime}+\Delta \sigma^{\prime}}{\sigma_{0}^{\prime}}\right)
$$

and for over consolidated clay

$$
S_{p}=\frac{C_{r} H}{1+e_{0}} \log \left(\frac{\sigma_{p}}{\sigma_{0}}\right)+\frac{C_{c} H}{1+e_{0}} \log \left(\frac{\sigma_{0}^{\prime}+\Delta \sigma^{\prime}}{\sigma_{p}}\right)
$$

Where: $\mathrm{S}_{\mathrm{p}}=$ the primary consolidation settlement, $\mathrm{e}_{\mathrm{o}}=$ initial void ratio, $\mathrm{C}_{\mathrm{c}}=$ compression index, $\mathrm{C}_{\mathrm{r}}=$ recompression index, $\mathrm{H}=$ thickness of the soil layer affected by embankment load, $\sigma_{o}^{\prime}=$ in-situ vertical effective stress, $\sigma_{p}=$ preconsolidation pressure, and $\Delta \sigma^{\prime}=$ stress increase in subsoil due to embankment loading.

The secondary consolidation can be calculated from equation (3) 


$$
S_{s}=\frac{C_{\alpha} H}{1+e_{o}} \log \frac{t_{f}}{t_{p}}
$$

Where: $\mathrm{S}_{\mathrm{s}}=$ the secondary consolidation settlement, $C_{\alpha}=$ the coefficient of secondary compression, $H=$ the thickness of the clay layer, $e_{\mathrm{o}}=$ initial void ratio at the end of primary stage, $t_{\mathrm{f}}=$ the time at which secondary compression is required and $t_{\mathrm{p}}=$ the time at end of primary consolidation [3].

\subsection{Finite Element Method}

Computer programs like GEO5 program have been developed to perform stability analysis and calculate the stresses and deformations for embankments and several structures. GEO5 program can be used to determine the total settlement and the rate of consolidation by two methods: finite element method by GEO5 FEM program and traditional methods by GEO5 settlement program.

\section{CASE STUDY: SKA EDEBY TEST EMBANKMENT}

Ska Edeby embankment was constructed in the year1961 at the west of Stockholm. The embankment height $=1.5 \mathrm{~m}$, the crest width $=4 \mathrm{~m}$ and slopes $1: 1.5$. The embankment constructed on soft clay layer with a depth of $15 \mathrm{~m}$. Settlement gauges and piezometers were installed at different places under and outside the embankment. The clay layer was divided into eight layers with different compressibility coefficients and (OCR) as shown in table (1).

From table (1) it was noticed that the upper $2 \mathrm{~m}$ have a value of (OCR) more than 1 , after about $6 \mathrm{~m}$ the clay layer becomes normally consolidated $(\mathrm{OCR} \approx 1)$. According to that, a high value of creep can be predicted [17].

The accuracy of models used to analyse the soft clay needs increasing the model parameters but increasing the model parameters leads to increasing the difficulties of evaluating the input parameters. For this reason, the most reliable methods to evaluate the efficiency of the models are to compare the models results with measured results from the cases histories.

Table (1) Clay Parameters (after Neher et al., 2001)

\begin{tabular}{|c|c|c|c|c|}
\hline Layer & $\gamma\left(\mathrm{kN} / \mathrm{m}^{3}\right)$ & K (m/day) & OCR & $\phi$ \\
\hline 1 & 14.2 & \multirow[t]{2}{*}{$8.64 * 10^{-5}$} & 14.1 & \multirow{8}{*}{$30^{\circ}$} \\
\hline 2 & \multirow[t]{2}{*}{14.4} & & 2 & \\
\hline 3 & & $7.0^{*} 10^{-5}$ & 1.2 & \\
\hline 4 & \multirow{5}{*}{16.1} & $6.22 * 10^{-5}$ & \multirow{5}{*}{1.0} & \\
\hline 5 & & $5.44 * 10^{-5}$ & & \\
\hline 6 & & $5.01 * 10^{-5}$ & & \\
\hline 7 & & \multirow[t]{2}{*}{$4.75 * 10^{-5}$} & & \\
\hline 8 & & & & \\
\hline
\end{tabular}

In this analysis, the total settlement due to a progressive pore pressure dissipation was determined after 1 year, 5 years, 10 years, 15 years, 20 years and 25 years from the embankment construction via GEO5 finite element program. After that, the calculated results were compared with the field results.

From figure (1) it can be seen that the measured results are fairly in agreement with the FEM results. 


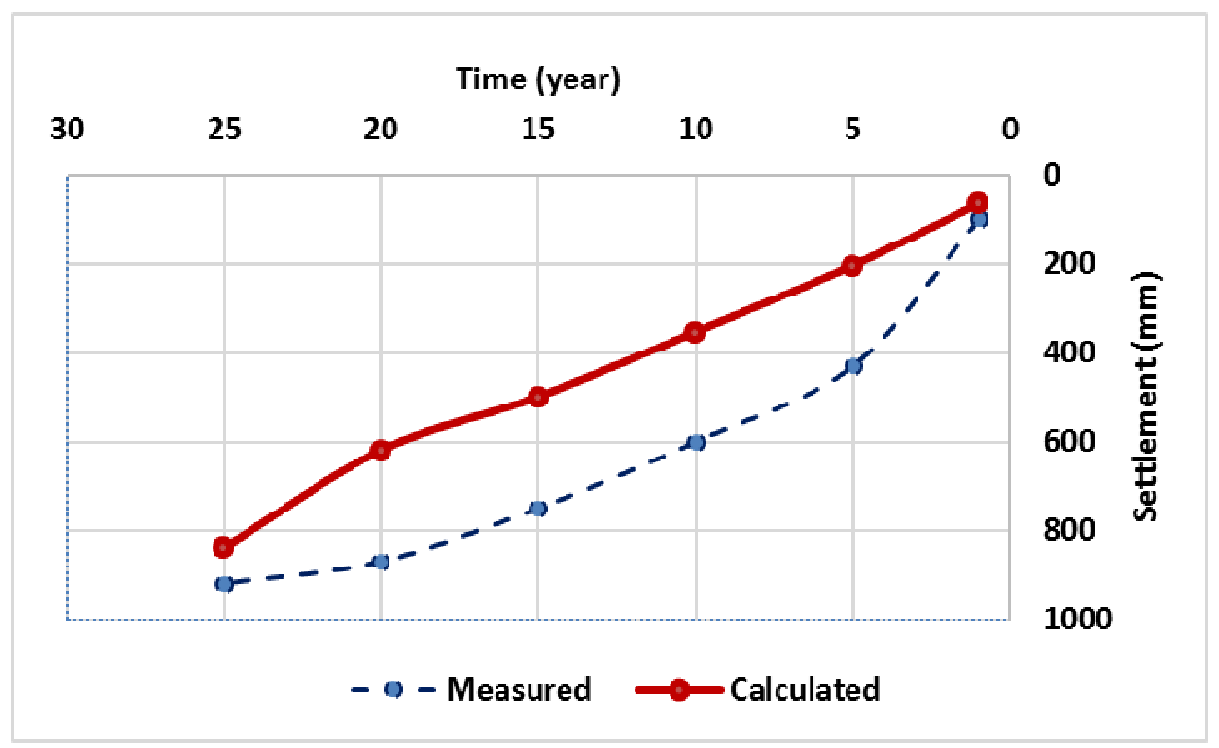

figure (1) A comparison between the measured results and the FEM results

\section{PARAMETRIC STUDY}

In this section, some factors were developed to study the sensitivity of some parameters such as the stiffness of clay layer, and the relation between the clay thickness $\left(h_{c}\right)$ and the width of the embankment base (B). The lateral extrusion due to the settlement of the embankment was also included.

\subsection{Effect of the Modulus of Elasticity for Clay Layer}

In this analysis, the influence of the soft clay layer stiffness on the settlement was studied. As the measured results for Ska Edeby embankment are in relatively agreement with the finite element results, so the same parameters and models are used in this analysis, only the values of the modulus of elasticity (E) for the clay layer were varied to be from 1 to $25 \mathrm{Mpa}$. The results of the numerical model indicated that the settlement decreases as the modulus of elasticity of clay layer increases as shown in figure (2).

Where $E=d \sigma / d \varepsilon$ (stress/strain), so an increase of modulus of elasticity meaning that the void ratio is decreasing due to stress increase, the permeability is decreasing also. According to that, the pore pressure dissipation in the clay layer is decreasing, as the permeability is decreasing.

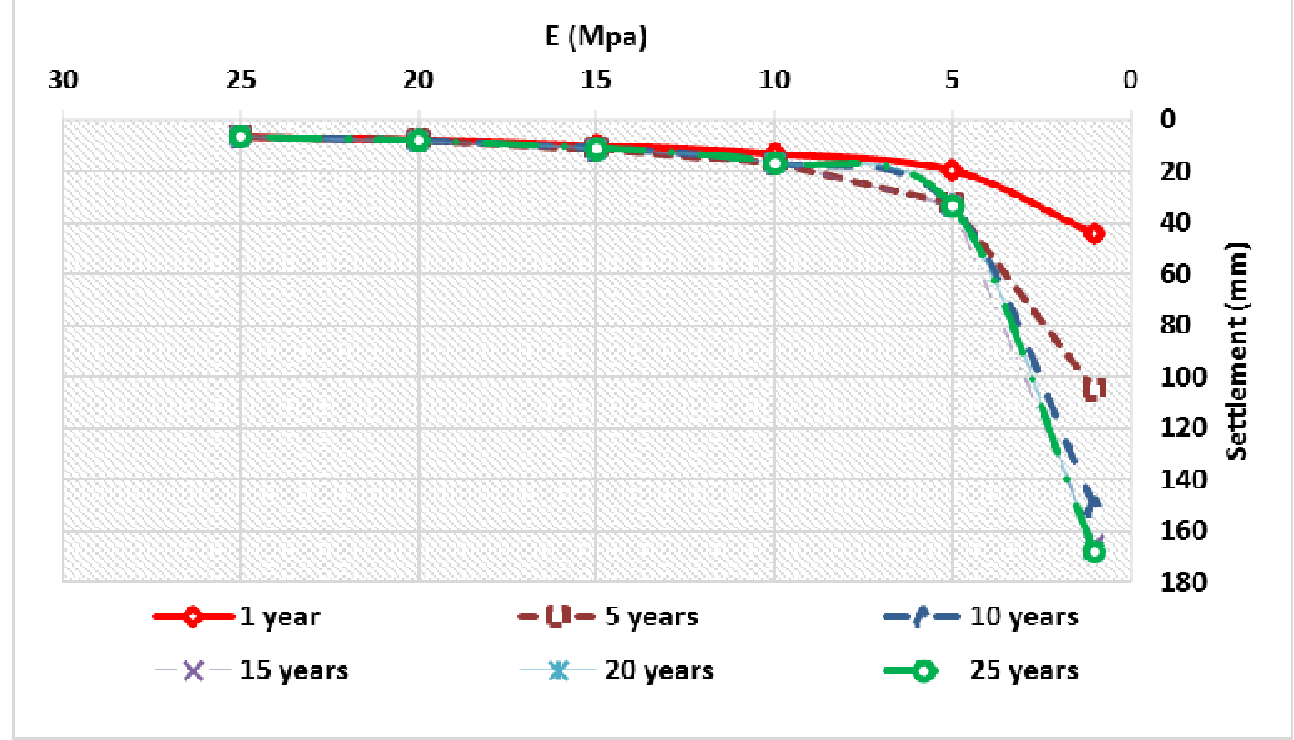

Figure (2) The relation between the modulus of elasticity and settlement 


\subsection{Clay Thickness $\left(h_{c}\right)$ and the Width of the Embankment Base (B)}

The geometry of the embankment plays an important role in the process of transfer the stresses to foundation soil and hence the induced settlements. Accordingly, the ratio between the thickness of the clay layer $\left(h_{c}\right)$ and the width of the embankment base (B) is very important in the analysis of the settlement. The model was used in this analysis is symmetric with $4 \mathrm{~m}$ height, the crest width $=8 \mathrm{~m}$, the base width $=20 \mathrm{~m}$, and the depth of clay layer $5 \mathrm{~m}$. The soil properties used in this analysis were as follows:

Embankment fill: sand with a unit weight $=20 \mathrm{kN} / \mathrm{m}^{3}$, cohesion $(\mathrm{c})=0$, friction angle $(\phi)=$ 35 degrees, modulus of elasticity $(\mathrm{E})=31 \mathrm{Mpa}$, horizontal coefficient of permeability $=10^{-2}$ $\mathrm{m} /$ day, vertical coefficient of permeability $=10^{-2} \mathrm{~m} /$ day, and Poisson's ratio $(v)=0.3$.

Clay layer: unit weight $=18 \mathrm{kN} / \mathrm{m}^{3}$, cohesion $(c)=18 \mathrm{kN} / \mathrm{m}^{2}$, friction angle $(\phi)=30$ degrees, modulus of elasticity $(\mathrm{E})=10 \mathrm{Mpa}$, horizontal coefficient of permeability=

$10^{-5} \mathrm{~m} /$ day, vertical coefficient of permeability $=10^{-5} \mathrm{~m} /$ day, and Poisson's ratio $(v)=0.4$.

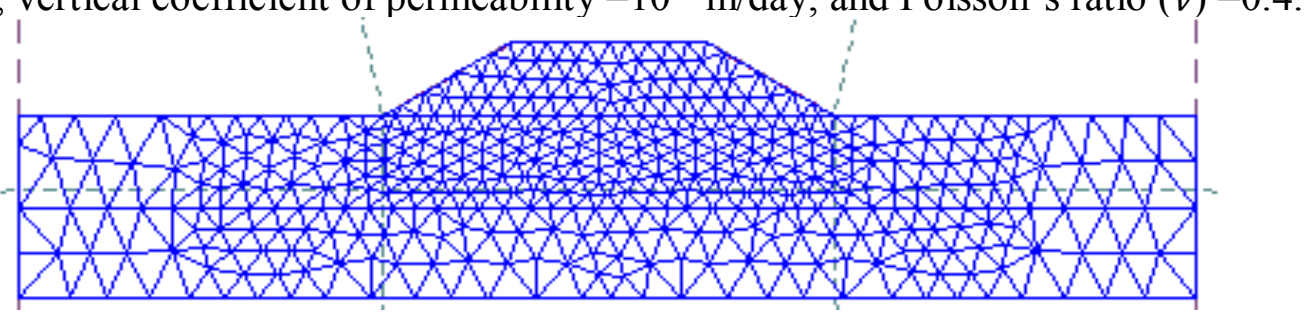

Figure (3) The finite element discretization of the model

The mesh generation result was as follows: number of nodes 2371, number of elements 1444 (region 812 , beam 158, interface 474 ) as shown in figure (3).

The model width ranges from 30 to $-30 \mathrm{~m}$ to permit a large enough area to ensure the boundaries at both sides have no effect on the results. To study the influence of the ratio $\left(h_{\mathcal{c}} / B\right)$, six finite element models were conducted and the ratio $\left(h_{c} / B\right)$ was varied as follows: $0.25,0.5,0.75,1,1.25$ and 1.5 .

To verify the results the same cases were recalculated using the traditional method.

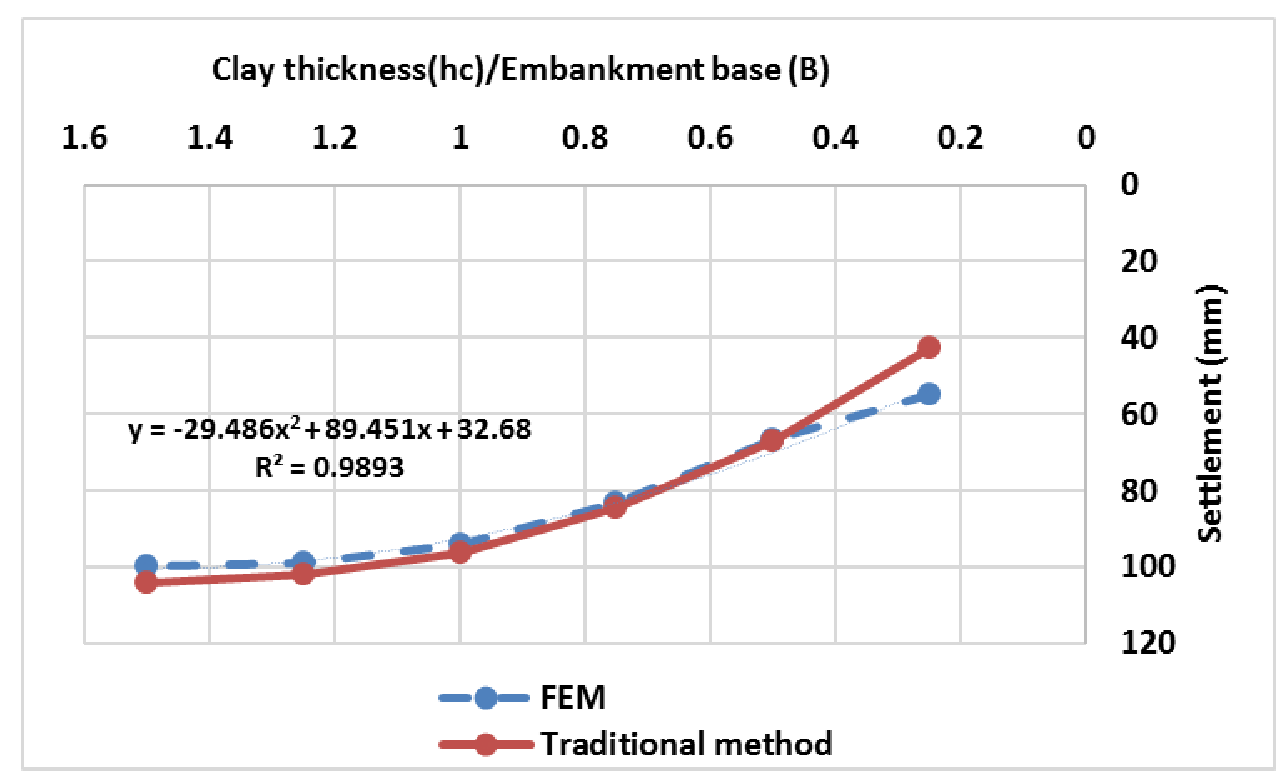

Figure (4) The relation between the ration (hc/B) and the maximum settlement

As shown in figure (4), the traditional method results are in good agreement with the finite element method. Additionally, it was found that the settlement increases as the ratio $(\mathrm{hc} / \mathrm{B})$ increases. 
For the embankment with $\left(\mathrm{h}_{\mathrm{c}} / \mathrm{B}\right)=0.25$, the main dissipation of pore pressure occurred after the first year from the embankment construction and the dissipation of pore pressure almost has finished, also the total settlement after one year equals $92.5 \%$ from the final settlement as shown in figure (5). Accordingly, it is preferable to construct the embankment with $\left(h_{d} / B\right)$ $=0.25$ to minimize the time required for settlement.

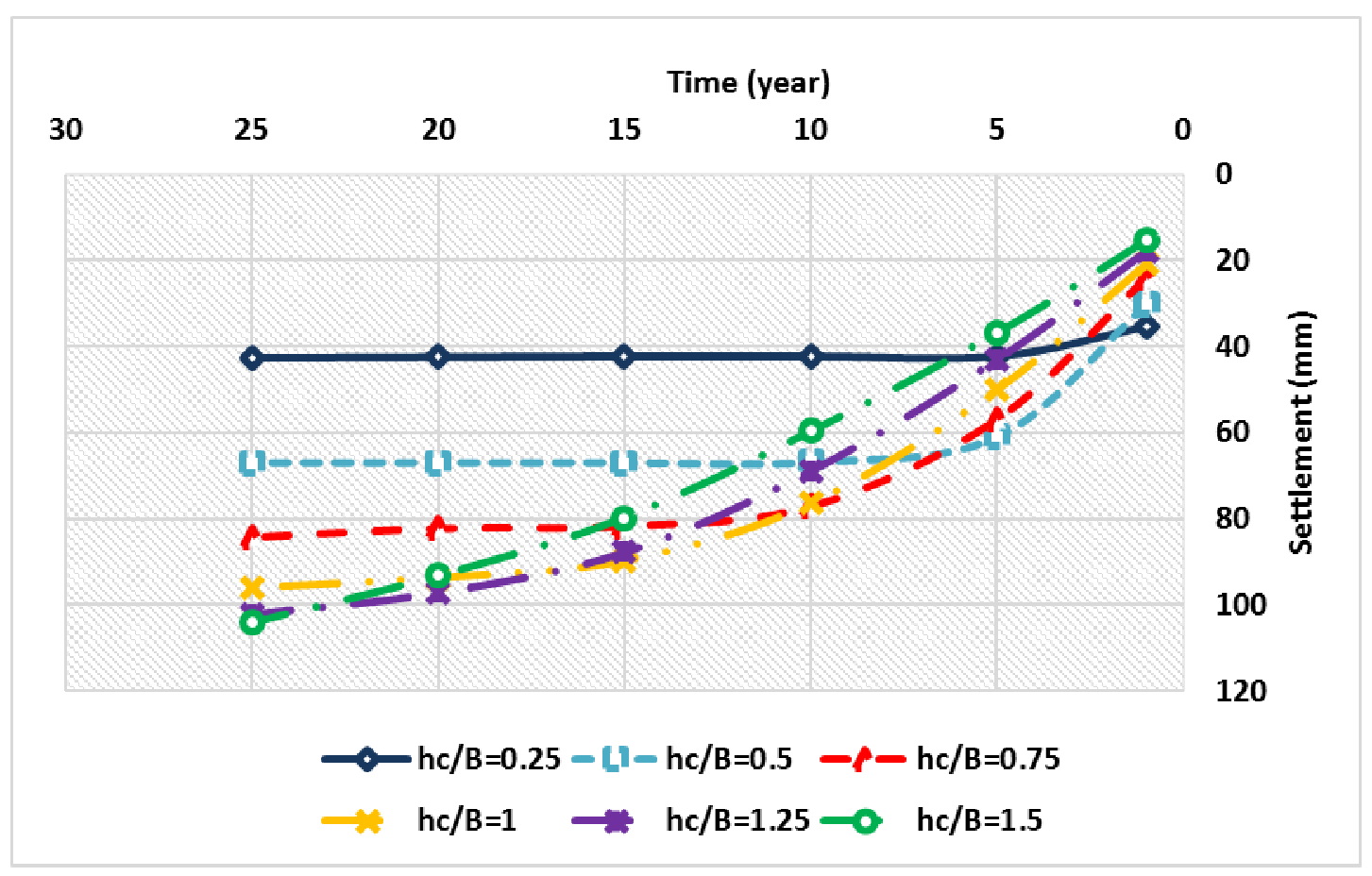

Figure (5) The rate of the settlement with various values of (hc/B)

\subsection{Lateral Extrusion}

In the case of an embankment founded on soft clay layer extend to a limited depth, outward shear stress can be induced by embankment loads, this stress besides the differential settlement of embankment results in an induced lateral extrusion of foundation at the toe of the embankment. In this section, the lateral extrusion of the embankment foundation is analyzed as shown in figures $6 \& 7$.
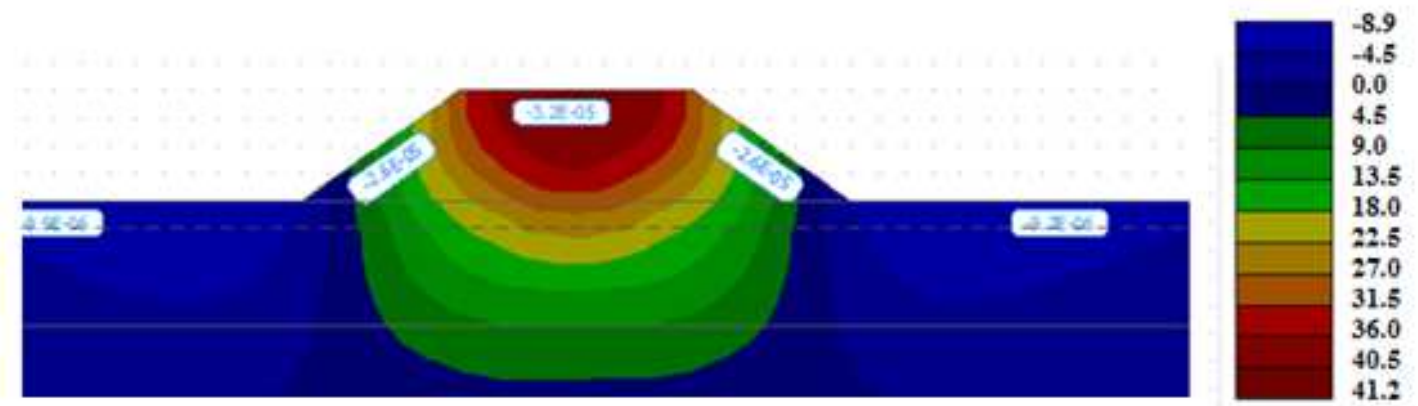

Figure (6) Distribution of the settlements after 7 days from embankment construction 


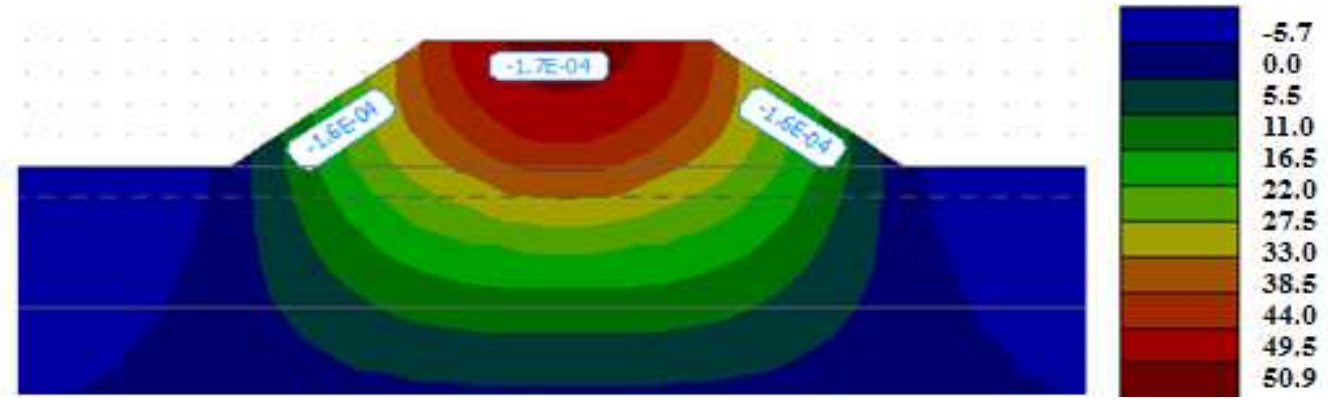

Figure (7) Distribution of the settlements after 1 year from embankment construction

The results of the numerical analysis showed that, the toe of the embankment is moved outwards with a little value reaches $4.5 \mathrm{~mm}$ after 7 days from the embankment construction, also the ground surface beside the toe of the embankment is moved outwards with a higher value reaches $8.9 \mathrm{~mm}$ as shown in figure (8). After 30 days, there isn't a significant change in the outward moving. After one year, the outward moving at the toe of the embankment dissipated completely and the outward moving at the ground surface beside the toe of the embankment became less and reached to $5.7 \mathrm{~mm}$. After 5 years, the value of the outward moving at the ground surface beside the toe of the embankment reached $4 \mathrm{~mm}$ and remained constant.

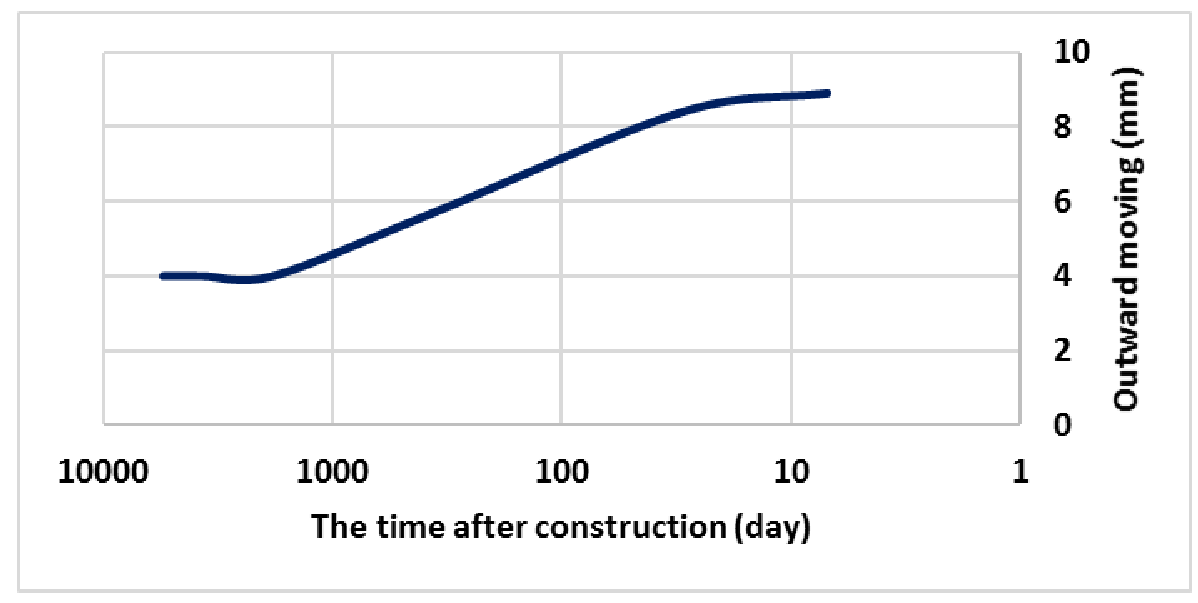

Figure (8) The relation between the time after the embankment construction and the outward moving

\section{CONCLUSIONS AND RECOMMENDATIONS}

The main objective of this study is to evaluate the effect of some factors on the settlement of soft clay soils under embankments. According to the analysis results, the following conclusions could be drawn:

- The measured values of the settlement are fairly in agreement with the FEM results.

- The settlement decreases, as the modulus of elasticity of clay layer increases. - The settlement value increases, as the ratio $(\mathrm{hc} / \mathrm{B})$ increases.

-It is preferable to construct the embankment on soft clay with $(\mathrm{hc} / \mathrm{B})=0.25$ to control the settlement under the embankment.

- The lateral extrusion decreases with time and its value at the top layers of soil are greater than the bottom layers.

\section{REFERENCES}

1. Brand, E.W. and Brenner, R.P., (1981)."Soft clay engineering", Elsevier Publications.

2. Das B.M., (2010) "Principles of Foundation Engineering", Cengage Learning, CT, USA.

3. Murthy, V.N. S., (2003)."Geotechnical engineering: principles and practices of soil mechanics and foundation engineering". Marcel Dekker,inc. New York. 
4. Leroueil, S. and Vaughn, P. R., (1990). "The general and congruent effects of structure in natural soils and weak rocks." Géotechnique 40, No. 3, pp. 467-488.

5. Smith's, (2014). "Elements of soil mechanics ". John Wiley \& Sons, Ltd, 9th. Ed.

6. Seah,T.H., Lai, K.C.,(2003)."Strength and Deformation Behaviour of Soft Bangkok Clay", Geotechnical Testing Journal, American Society for Testing and Materials, Volume 26, Issue 4, pp.421-431.

7. Balasubramaniam, A. S., Cai, H., Zhu, D., Surarak, C., and Oh, E. Y. N., (2010) "Settlements of Embankments in Soft Soils" Geotechnical Engineering Journal of the SEAGS \& AGSSEA Vol 41 No.2. ISSN 0046-5828.

8. Wijeyakulasuriya,V., Hobbs,G., and Brandon, A., (1999). "Some experiences with performance monitoring of embankments on soft clays", Proc. 8th Australia New Zealand Conference on Geomechanics, Institution of Engineers Australia: Hobart, pp 783-788.

9. Leroueil,S., Magnan, J. and Tevenas, F. (1990). "Embankments on soft clays." New York, Ellis Horwood, 360 p.

10. Long, P.V., Bergado, D.T. and Balasubramaniam, A.S.,(1996). "Stability Analysis of Reinforced and Unreinforced Embankment on Soft Ground", Geosynthetics International Journal, Volume 3, Issue 5.

11. Vipulanandan,C., Bilgin, Ö., Y Jeannot Ahossin Guezo, Vembu, K.

12. and Erten, M. B.,(2008). "Prediction of embankment settlement over soft soils" University of Houston Department of Civil and Environmental Engineering. Houston, Texas 77204-4003.

13. Leroueil, S. (1994). "Compressibility of Clays: "Fundamental and Practical Aspects." ASCE Geotechnical Special Publication No. 40, Conference on Vertical and Horizontal Deformations of Foundations and Embankments, Proc. of Settlement '94, College Station, Texas, Vol. 1, pp. 57-76.

14. Nagaraj, T.S. and Miura, N. (2001). "Soft Clay Behavior Analysis and Assessment." A.A. Balkema, Rotterdam, ISBN 9058093298.

15. British Standards Institute. BS 8006-1, (2010). "Code of Practice for Strengthened/ Reinforced Soils and other Fills", London: British Standards.

16. Toshifumi S., Takayuki S., Akira M. et al., (2019) "Prediction of long-term settlement and evaluation of pore water pressure using particle filter" Soils and Foundations 59 (2019) 67-83.

17. Heng Wang, Ling-Ling Zeng, Jian-Wen Ding, and Zhen-Shun Hong ,(2019). "Settlement of Funing Natural Clays under 14-Year Embankment Loads: A Case Study." Advances in Civil Engineering Volume 2019, Article ID 8297459, 11 pages.

18. Neher, H.P., Wehnert, M., and Bonnier, P.G. 2001. "An evaluation of soft soil models based on trial embankments". In Proceedings of the 10th International Conference on Computer Methods and Advances in Geomechanics, Tucson, Ariz., 2001. Edited by Ch. Desai. Balkema, Rotterdam, the Netherlands. pp. 373-378. 